\title{
Pemanfaatan Limbah Cabai (Capsicum Annum) sebagai Alternatif Mempercepat Pematangan Buah Alpukat secara Alami
}

\author{
The Use of Chili Waste (Capsicum Annum) as an Alternative to Quicken The Growth \\ of Avocado
}

\author{
Fatih Dzulfiqar ${ }^{*}$, Muhammad Hafizh Alfayez, Mirza Hukma Shobiyya, Jun Jun Junaedi \\ Sekolah Menengah Atas Islam Sinar Cendekia, Serpong, Tangerang Selatan, Banten \\ *Surel: fatihdzulfiqar@gmail.com
}

\begin{abstract}
INFO ARTIKEL
Abstract

Diterima 16 Oktober 2019

Direvisi 11 November 2019

Disetujui 27 Desember 2019

Nomor Artikel 201910

Halaman 21-25

Kata kunci:

Buah alpukat

Proses pematangan

Cabai (capsicum annum)

Zat atktif (capcaisin)

Avocado is one of the most popular fruit among people because avocado is one of the tropical fruits that grows well in Indonesia, and can be found in various regions. Due to the increasing demand of avocados, this gives a bigger challenge for avocado farmers to find new method on how to ripen the fruit in a short time period to comply with the increase market demands. Here, we have found a technique that will naturally ripen the fruit, by using chili waste (Capsicum annum). In this research, the identification of problem is, can we use chili waste as an alternative to ripen the avocado? Also, what are the contents in chili so that it can ripen avocados in a short time period. The objective of this research is to discover the use of chili waste (Capsicum annum) as an alternative to naturally ripen the fruit. The research method used in this study is experimental method. The research subjects are two unripe avocados which are given three different treatments. The results shows that the avocado after two days treatment with chili, relatively grew faster compared to the avocado that was not treated. This is because of the active substance content in chili (Capcaisin) gives a stimulating effect towards the growth enzyme in the avocado. Hence, based on the results of this research, we can conclude that chili waste can be used as an alternative to help the process of avocado ripening.
\end{abstract}

Keywords : Avocado, ripening process, chili (capsicum annum), active substanc (capcaisin)

\begin{abstract}
Abstrak
Alpukat merupakan buah yang sangat digemari oleh sebagian besar masyarakat karena alpukat adalah salah satu tumbuhan buah tropis yang sangat baik tumbuh di Indonesia, dan hampir dapat ditemukan di berbagai daerah. Namun seiring dengan permintaan buah alpukat yang semakin meningkat, hal ini memberikan tantangan besar di kalangan petani buah alpukat untuk mencari cara mempercepat pematangan buah tersebut dengan maksud memenuhi permintaan pasar yang semakin tinggi. Penulis menemukan teknik mematangkan buah alpukat secara alami, yakni dengan memanfaatkan limbah cabai (capsicum annum). Permasalahan pada penelitian ini adalah apakah limbah cabai dapat dijadikan sebagai alternatif pematangan buah alpukat? Kemudian, apakah kandungan zat yang terdapat di dalam cabai sehingga dapat mempercepat proses pematangan buah alpukat. Tujuan penelitian ini untuk mengetahui pemanfaatan limbah cabai sebagai alternatif mempercepat pematangan buah alpukat. Pada penelitian ini digunakan dua buah alpukat mentah yang diberikan perlakuan berbeda dalam penelitian. Hasil penelitian menunjukan bahwa alpukat yang diberikan cabai setelah dua hari relatif lebih cepat matang dibandingkan alpukat yang tidak diberikan cabai. Hal ini dikarenakan kandungan zat aktif dalam cabai (Capsaicin) memberikan efek aktif terhadap enzim pematangan yang ada di dalam buah alpukat. Oleh karenanya bahwa limbah cabai dapat dijadikan alternatif membantu proses pematangan buah alpukat.
\end{abstract}




\section{PENDAHULUAN}

Alpukat (persea americana) merupakan salah satu tumbuhan buah tropis yang sangat baik tumbuh di Indonesia. Pada umumnya buah ini dapat ditemukan di berbagai daerah khususnya daerah dataran tinggi. Buah alpukat sangat digemari oleh sebagian besar masyarakat. Hal ini dikarenakan buah alpukat kaya akan manfaat bagi kesehatan tubuh, diantaranya sebagai sumber vitamin $\mathrm{C}$, kesehatan kulit, melancarkan pencernaan, dan lain sebagainya [1]. Disebabkan memiliki banyak manfaat ini, buah alpukat menjadi target oleh hampir sebagian besar masyarakat, dimana hal ini seiring juga dengan meningkatkanya permintaan buah alpukat oleh masyarakat.

Permintaan pasar terhadap meningkatnya kebutuhan konsumsi buah alpukat berdampak besar terhadap petani dan pedagang buah alpukat. Tantangan besar di kalangan petani buah alpukat adalah mencari cara memproduksi buah alpukat dan mempercepat proses pematangan buah tersebut untuk memenuhi permintaan pasar yang semakin tinggi. Selama ini banyak hal yang telah dilakukan oleh sebagian petani dan pedagang buah alpukat dalam proses mempercepat pematangan buah tersebut. Seperti dalam hal penanaman buah alpukat metega miki, daerah tanam sebaiknya berpasir, liat dan agak lempung yang memiliki kaya humus unsur hara serta gembur. Suhu udara antara $15-30^{\circ} \mathrm{C}$ dengan curah hujan 56 bulan basah dengan derajat keasaman $\mathrm{pH}$ antara 6 sampai dengan 7 [2]. Profesor Neena Mitter dari Australia mengembangkan penggunaan kultur jaringan untuk menghasilkan pohon alpukat yang lebih cepat berbuah dan lebih efisien [3]. Sementara dalam mempercepat pematangan buah alpukat bisa dilaksanakan dengan cara seperti memasukkan dalam kantung kertas, menambahkan buah lain, menambahkan tepung dan memanggang [4].

Meski demikian, hasil studi pendahuluan tim penulis ketika mengunjungi salah satu pedagang buah alpukat di kawasan Tangerang Selatan, Banten, mendapatkan hasil data bahwa pedagang tersebut menemukan kendala terkait proses teknik mempercepat pematangan buah alpukat, dimana kebanyakan pematangan buah alpukat tidak bisa diprediksi secara pasti. Penulis menarik kesimpulan dari hasil studi pendahuluan tersebut bahwa masih terdapat pedagang yang mendapati ketidakpuasan dan ini menjadi salah satu kendala dalam proses pematangan buah alpukat. Hal ini menjadi observasi utama dalam menemukan masalah di kalangan masyarakat dan menjadi perhatian kami. Dalam rangka memberikan solusi atas masalah tersebut, kami mengusulkan metode atau cara baru untuk menangani permasalahan pematangan buah alpukat dengan cara memanfaatkan cabai untuk mempercepat pematangan buah alpukat. Kenapa menggunakan cabai? Karena kandungan zat aktif senyawa capsaicin dalam cabai (capsicum annum) [5] dapat memberikan efek aktif terhadap enzim pematangan yang ada di dalam buah alpukat sehingga dapat membantu mempercepat pematangan buah alpukat.

Berdasarkan latar belakang di atas penulis melakukan penelitian terhadap proses pematangan buah alpukat dengan memanfaatkan cabai sebagai katalisator. Tujuan dari penelitian ini adalah mengetahui manfaat biji cabai dapat mempercepat pematangan buah alpukat, untuk mengetahui faktor apa yang menyebabkan biji cabai dapat mempercepat pematangan buah alpukat, untuk mengetahui cara memanfaatkan biji cabai untuk mempercepat pematangan pada buah alpukat secara alami. Dan untuk mengetahui perbandingan hasil perlakuan antara alpukat tanpa biji cabai (sebagai referensi) dengan alpukat yang diberi perlakuan biji cabai.

\section{METODE PENELITIAN}

Berdasarkan latar belakang yang telah diuraikan sebelumnya, maka perumusan masalah dalam penelitian ini adalah :

1. Apakah biji cabai dapat mempercepat pematangan buah alpukat?

2. Faktor apa yang menyebabkan biji cabai dapat mempercepat pematangan buah alpukat?

3. Bagaimana cara memanfaatkan biji cabai untuk mempercepat pematangan pada buah alpukat secara alami?

4. Bagaimana perbandingan hasil perlakuan antara alpukat tanpa biji cabai dengan alpukat yang diberi perlakuan biji cabai?

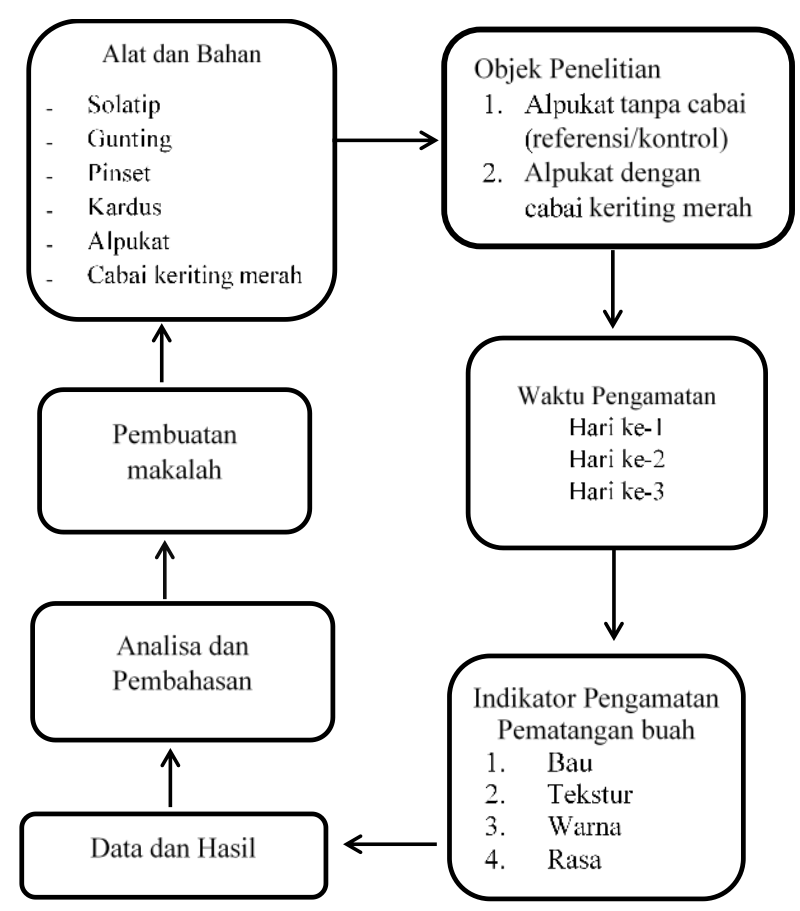

Gambar 1.Alur penelitian proses pematangan buah Alpukat. 
Penelitian ini termasuk penelitian pengembangan (innovation research) dengan metode kuantitatif yang dilakukan secara eksperimen. Adapun alat dan bahan yang digunakan diantaranya solatip, gunting, pinset, kardus, buah alpukat dan cabai keriting. Di bawah ini adalah prosedur penelitian yang kami lakukan pada penelitian kali ini (Gambar 1), yang secara visual digambarkan pada Gambar 2.

1. Mempersiapkan alat dan bahan

2. Cabut ujung tangkai pada buah alpukat

3. Belah cabai keriting

4. Letakkan biji cabai pada ujung alpukat. Sementara pada sampel referensi (kontrol) dibiarkan tanpa biji cabai.

5. Sediakan kardus sebagai tempat penyimpanan

6. Masukkan keempat objek ke dalam kardus

7. Masing-masing perlakuan dilakukan pengulangan sebanyak 1 kali
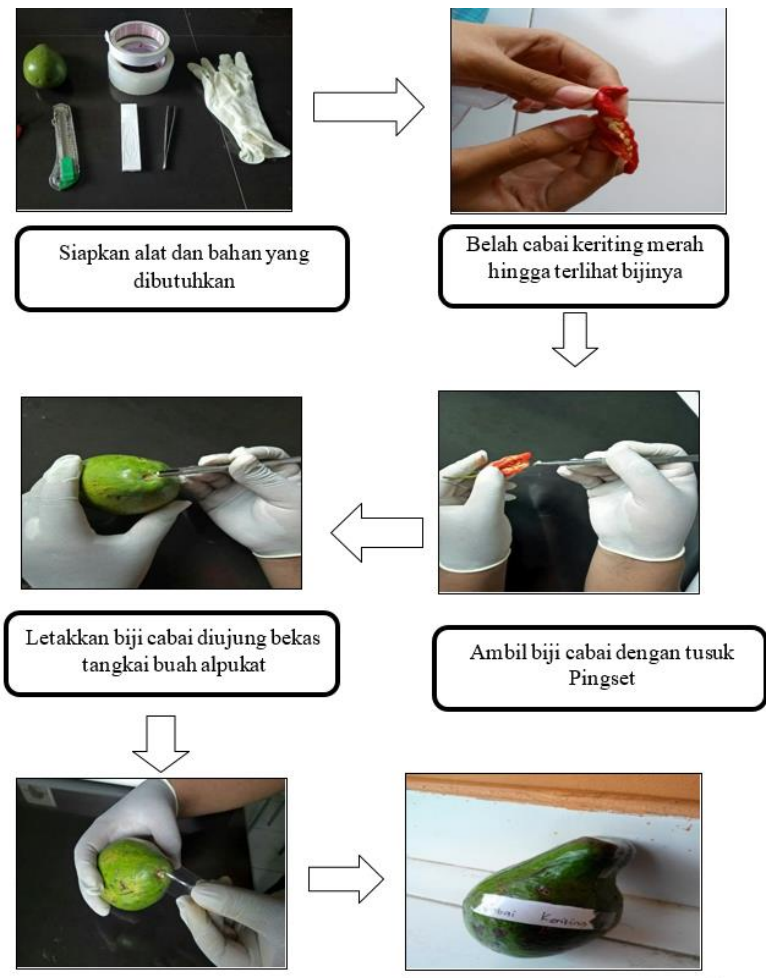

Tutup ujung buah alpukat dengan solatip

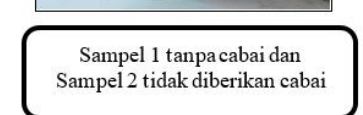

Gambar 2. Gambaran aktivitas eksperimen proses pematangan buah alpukat dengan pemanfaatan limbah cabai.

\section{HASIL DAN PEMBAHASAN}

Tabel 1 menunjukkan data tingkat kematangan buah alpukat dibandingkan dengan variabel kontrol dengan perlakuan Hari I, II, dan III. Terlihat bahwa, pada alpukat tanpa penambahan cabai (referensi) di Hari I tingkat kematangan belum terlihat, sementara di Hari II dan III belum matang tetapi sudah sedikit lunak. Sementara pada alpukat yang diberi cabai keriting merah (variabel perlakuan), di Hari I tingkat kematangannya belum terlihat sebagaimana hasil sampel referensi, kemudian di Hari II tingkat kematangannya sudah sedikit meningkat dan cukup lunak. Di Hari III kematangannya sudah sempurna dan sudah lunak.

Tabel 1. Pengamatan tingkat kematangan.

\begin{tabular}{|c|c|c|}
\hline \multirow{2}{*}{ HARI } & \multicolumn{2}{|c|}{ OBJEK } \\
\cline { 2 - 3 } & $\begin{array}{c}\text { Referensi/ } \\
\text { kontrol }\end{array}$ & $\begin{array}{c}\text { Alpukat dengan } \\
\text { penambahan } \\
\text { cabai keriting } \\
\text { merah }\end{array}$ \\
\hline I & 0 & 0 \\
\hline II & 20 & 60 \\
\hline III & 20 & 100 \\
\hline
\end{tabular}

Keterangan :

0 : Belum matang dan tekstur masih keras

1-20 : Belum matang dan tekstur sedikit lunak

21-40 : Belum matang dan tekstur cukup lunak

41-60 : Sedikit matang dan tekstur cukup lunak

61-80 : Matang dan lunak

81-100 : Matang sempurna

Gambar 3 menunjukkan grafik tingkat aroma buah alpukat yang dibandingkan dengan sampel variable kontrol. Didapatkan hasil bahwa pada alpukat tanpa penambahan cabai (referensi/kontrol), pada Hari I aroma dari buah alpukat belum tercium hingga Hari II dan III aromanya sudah tercium tetapi hanya sedikit. Sementara pada alpukat dengan penambahan cabai keriting merah (variabel perlakuan), di hari pertama alpukat yang diberi cabai keriting merah belum berbau. Kemudian di Hari II memiliki peningkatan yang cukup drastis dengan aroma yang baik dan di Hari III aroma dari buah alpukat dengan cabai keriting merah sudah beraroma seperti buah matang sempurna.

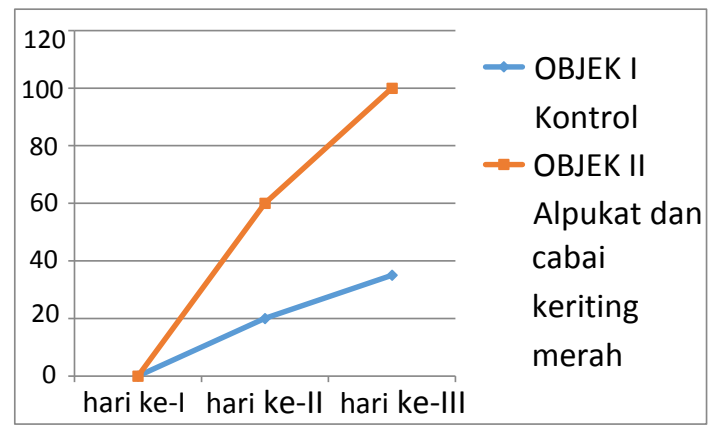

Keterangan :

0-30 : Tidak ada bau khas matang buah

31-50 : Mulai beraroma sedikit tanda matang buah

51-80 : Beraroma khas buah matang

81-100 : Beraroma seperti buah matang.

Gambar 3. Grafik tingkat kematangan tingkat aroma 


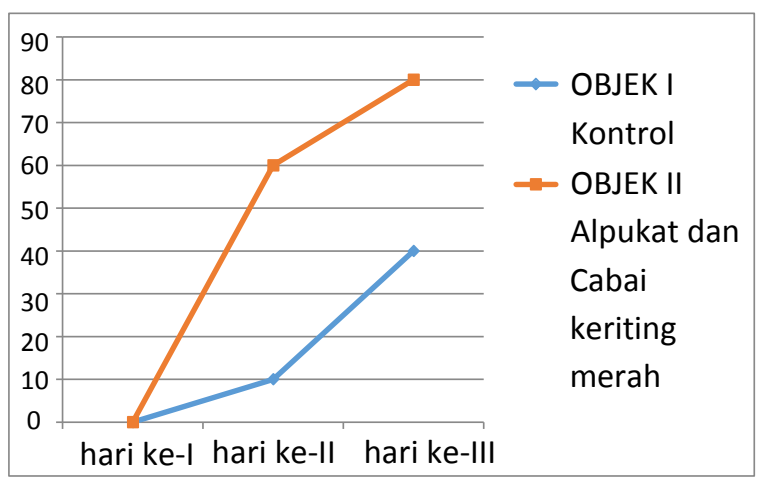

Keterangan :

$0 \quad$ : Tekstur masih sangat keras dan kasar $(+++)$

1-20 : Tekstur masih keras dan kasar (++)

21-40 : Tekstur masih keras dan kasar $(+)$

41-60 : Tekstur sedikit lembut

61-80 : Tekstur lembut

81-100 : Tekstur sangat lembut

Gambar 4. Grafik tingkat kematangan tingkat tekstur.

Gambar 4 menunjukkan analisis tingkat tekstur buah alpukat, dan didapatkan hasil sebagai berikut.

a. Alpukat tanpa penambahan cabai (referensi/kontrol)

Buah alpukat di hari ertama teksturnya masih sangat keras, di hari kedua pun sama dengan tektur di hari pertama yaitu masih sangat keras. Kemudian di hari ketiga berubah tekstur kerasnya menadi sedikit berkurang.

b. Alpukat dan Cabai Keriting Merah (variabel perlakuan) Tektur buah alpukat dengan cabai keriting merah di hari pertama masih sangat keras. Peningkatan tekstur menjadi sedikit lebih lembut dan di hari ketiga tekturnya menjadi lembut.

Tabel 2. Pengamatan tingkat warna.

\begin{tabular}{|c|c|c|}
\hline \multirow{2}{*}{ HARI } & \multicolumn{2}{|c|}{ OBJEK } \\
\cline { 2 - 3 } & $\begin{array}{c}\text { I } \\
\text { Referensi/ } \\
\text { kontrol }\end{array}$ & $\begin{array}{c}\text { Alpukat dan } \\
\text { cabai keriting } \\
\text { merah }\end{array}$ \\
\hline hari ke-I & 0 & 0 \\
\hline hari ke-II & 10 & 20 \\
\hline hari ke-III & 10 & 40 \\
\hline
\end{tabular}

Tabel 2 merupakan data analisis tingkat warna, di mana pada alpukat tanpa penambahan cabai (referensi/kontrol), di Hari I warna pada alpukat masih hijau dan untuk Hari II serta Hari III tidak ada perubahan warna sama sekali,yaitu warnanya masih hijau seperti hari pertama dilakukan percobaan. Sementara pada alpukat dan cabai keriting merah (variabel perlakuan), warna pada alpukat dengan cabai keriting merah di Hari I masih hijau. Di Hari II warnanya berubah menjadi hijau kekuningan, dan pada Hari III warnanya menjadi hijau kecokelatan.

Berdasarkan hasil pengamatan di atas maka dapat disimpulkan bahwa biji cabai kriting dapat mempercepat pematangan buah alpukat. Hal ini dapat terjadi disebabkan dari zat capsaicin $\left(\mathrm{C}_{18} \mathrm{H}_{27} \mathrm{NO}_{3}\right)$ yang menimbulkan efek panas yang tinggi menyebabkan suhu meningkat (lihat Gambar 5). Adanya kenaikan suhu ini berakibat aktifitas dari respirasi menjadi meningkat. Respirasi yang tinggi menghasilkan energi yang banyak sehingga fisiologi dalam buah bekerja dengan baik, berakibat pula pada fungsi etilen yang bekerja lebih aktif di pematangan buah alami.Capsaicin mempunyai berat molekul 305,40 g/mol [6], dan merupakan senyawa nonpolar yang memilikibeberapa gugus polar terhadap hidrogen yang berikatandengan air [7]. Hal ini menyebabkan capsaicin tidak larut dalam air [8].Hipotesis kami, cabai mengandung zat capsaicin yang dapat merangsang hormon pematangan buah Alpukat (Biokatalisator pematangan buah Alpukat) dan juga limbah biji cabai dapat membantu membantu mempercepat pematangan buah Alpukat secara alami.<smiles>COc1cc(CNC(=O)CCCC/C=C/C(C)C)ccc1O</smiles>

Gambar 5. Formula struktur capsaicin dari cabai [9].

Menurut Simbolon, gas etilen akan mempercepat proses pematangan [10]. Gas ini sangat penting pengaruhnya terhadap pemasakan pada buah klimakterik seperti buah alpukat ini. Sedangkan suhu juga berpengaruh terhadap peningkatan produksi etilen. Suhu meningkat selama proses respirasi menyebabkan penurunan $\mathrm{O}_{2}$ dan peningkatan $\mathrm{CO}_{2}$.

Peletakan biji cabe pada bekas tangkai buah, membuat kerja dari kapsaisin menjadi lebih baik. Karena bekas luka tersebut ditambah dengan penambahan biji cabe berefek juga pada proses respirasi yang memicu peningkatan konsentrasi gas etilen. Konsentrasi gas etilen yang cukup tinggi ini yang membuat pematangan buah alpokat menjadi lebih cepat. Buah matang mempunyai ciri-ciri, yaitu aromanya lebih tercium,teksturnya lebih lembut, dan warnanya lebih kecokelatan yang menandakan matang. 


\section{KESIMPULAN}

Berdasarkan hasil penelitian yang telah dilakukan maka dapat diambil kesimpulan bahwa biji cabai merah keriting dapat mempercepat proses pematangan buah. Proses pematangan buah dengan biji cabai keriting merah dilakukan dengan cara meletakkan biji cabai keriting merah ke ujung alpukat kemudian ditutup dengan solatip dan didiamkan serta diamati selama tiga hari. Faktor penyebab lebih cepatnya pematangan buah dengan biji cabai keriting karena adanya kandungan kapsiasin dalam cabai. Dengan pemberian biji cabai yang mengandung zat kapsaisin meningkatkan laju pematangan buah dibandingkan dengan sampel referensi/kontrol. Penelitian ini diharapkan dapat mempercepat pematangan buah dengan alami, memberikan informasi bahwa ada manfaat lain dari biji cabai dan dapat memberikan pengetahuan keadaan masyarakat.

\section{UCAPAN TERIMAKASIH}

Makalah ini ditulis merujuk pada hasil penelitian yang dikompetisikan pada "Chemistry Education Fair 2018" di UIN Syarif Hidayatullah. Penulis mengucapkan terima kasih kepada SMA Islam Sinar Cendekiayang telah memberikan dorongan dan bantuan sehingga penelitian ini dapat dilaksanakan.

\section{DAFTAR PUSTAKA}

[1] Samson, J.A. 1980. Tropical Fruits. Longman Inc., New York.

[2] Yulistia Budianti Soemarie, Tri Astuti, Nur Rochmah, 2016. "Formulasi sediaan salep ekstrak etanol daun alpukat (Persea americana Mill.) sebagai antiacne", Jurnal Ilmiah Manuntung, 2(2), 224-232.

[3] Hiti-Bandaralage, Jayeni , Hayward, Alice and Mitter, Neena (2017). Micropropagation of Avocado (Persea americana Mill.). American Journal of Plant Sciences 8 (11) 2898-2921.

[4] Jusuf Wahyudi, Roni Herdian Saputra. 2016. "Penentuan korelasi tingkat kematangan buah alpukat (Persea americana mill) terhadap gravitasi spesifik", Agritepa, Vol. II, No.2, pp 153-164.

[5] Sukrasmo, K., Tarini, S., Sugiarso, NC. 1997. Kandungan kapkaisin dan dihidrokapkaisin pada berbagai buah capsicum. JMS. Vol. 2, FMIPA ITB, pp. 28-34.

[6] Iis Nuraeni, Tina Rostinawati. 2018. Review : Perkembangan produksi hasil metabolisme sekunder capsaisin dengan berbagai metode in vitro. Farmaka Suplemen Vo. 16 No. 1, pp. 231 239.
[7] Lutvianto Pebri Handoko, Yeni Variyana, Mahfud. Studi Efektivitas Ekstraksi (Capsaicin) dari Cabai (Capsicum) Dengan Metode MASE(Microwave Assisted Soxhlet Extraction), JURNAL TEKNIK ITS Vol. 6, No. 2 (2017), pp. F384 - F386.

[8] Cairns, D. 2014. Intisari kimia farmasi. Penerbit Buku Kedokteran EGC. Jakarta

[9] Nelson, E.K., Dawson L.E. 1923. The constitution of capsicum. III. J. Am. Chem. Soc. 45, pp. 2179-2181.

[10] Simbolon, Junice. 1991. Desain Peti Kayu untuk Kemasan Distribusi Buah Apel Segar (Malussylvesteris Mill.). Fakultas Pertanian IPB. Bogor. 